УДК 614.2(07)

\title{
СУЧАСНІ НАВЧАЛЬНІ ТЕХНОЛОГІЇ У ПРАКТИЦІ ПІСЛЯДИПЛОМНОЇ МЕДИЧНОЇ ОСВІТИ
}

\author{
О. С. Никоненко, С. Д. Шаповал, С. М. Дмитрісва
}

Запорізька медична академія післядипломноїосвіти

\section{MODERN TECHNOLOGIES OF STUDIES IN THE POST-GRADUATE EDUCATION OF DOCTORS}

\author{
O. S. Nykonenko, S. D. Shapoval, S. M. Dmytriyeva \\ Zaporizhian Medical Academy of Post-Graduate Education
}

\begin{abstract}
У статті наведено досвід впровадження в післядипломну підготовку лікарів сучасних технологій організації навчального процесу у ДЗ “Запорізька медична академія післядипломної освіти МОЗ України”. Висвітлено деякі проблемні питання розробки та впровадження нових організаційних форм навчання у післядипломній підготовці лікарів. Зроблено висновок про необхідність застосування різних організаційних навчальних форм відповідно до потреб кожної цільової групи суб'сктів навчання.

Some questions of problems in relation to introduction of new organizational educational technologies at the post-graduate teaching of medical specialists at Zaporizhian Medical Academy of Post-Graduate education are considered in the article. The problem of development and introduction of new organizational forms of training and modern educational technologies are discussed. Necessity of forming of flexible system of post-graduate education of doctors with introduction of different organizational forms and technologies to requirements of each target group of subjects of training are proved.
\end{abstract}

Вступ. Сучасним етапом реформування системи вищої медичної освіти України відповідно до стратегічної мети приведення іії у відповідність до міжнародних освітніх стандартів передбачено активне впровадження у післядипломну підготовку лікарів інноваційних освітніх технологій та перегляд традиційних конструкцій організації навчання з формуванням спрямованої мотивації всіх категорій суб'єктів навчання до безперервного професійного розвитку. Сьогодні розробка та апробування нових організаційних форм післядипломної підготовки медичних фахівців, орієнтація на світові досягнення медичної науки і практики, спрямованість навчання щодо потреб практичної охорони здоров'я, впровадження в педагогічний процес новітніх, зокрема комп'ютерних і телемедичних технологій навчання та контролю знань $є$ умовою успішності освітньої діяльності медичних ВНЗ післядипломної освіти [1-4].

Основна частина. На виконання завдань освітньої реформи у ДЗ “Запорізька медична академія післядипломної освіти МО3 України” (надалі - ДЗ “ЗМАПО МОЗУ”) здійснюється моніторинг щодо узагальнення та аналізу досвіду застосування інноваційних освітніх технологій у педагогічній практиці закладу [5].
Поряд з впровадженням інноваційних освітніх технологій та новітніх форм організації навчального процесу (дистанційне навчання, телемедичні технології, організація інтенсивної підготовки лікарів шляхом короткотривалих циклів інформації та стажування, забезпечення безперервного навчання лікарів на постійно діючих проблемних семінарах), викладачі академії прагнуть зберегти кращі особливості національної системи медичної освіти 3 виховання сучасного спеціаліста відповідно до принципів клінічного навчання, біоетики та доказової медицини. На даний час у межах додаткових програм для слухачів ДЗ “ЗМАПО МОЗУ” організовано три елективних курси: "Медичне право”, “Біоетика та біобезпека", “Цивільний захист та медицина катастроф”, а викладання базових медичних дидисциплін здійснюється за сучасними клініко-економічними стандартами відповідно до міжнародного досвіду на підставі поглиблення практичної спрямованості занять та удосконалення технічних засобів навчання.

У межах регламентованих термінів традиційних форм організації післядипломної підготовки лікарів (спеціалізація, тематичне удосконалення, стажування) не завжди є можливість щодо забезпечення гнучкості навчання стосовно реальних умов роботи су-

( О. С. Никоненко, С. Д. Шаповал, С. М. Дмитрієва 
часного лікаря. Тому в академії активно діє програма 3 впровадження елементів дистанційного навчання у педагогічний процес. Дистанційні технології використовуються в реалізації проекту зі створення i функціонування системи самонавчання викладачів; при організації циклів тематичного удосконалення лікарів вибірково застосовуються кейс-, TV-, мережні або технології мобільного Інтернету.

Опрацювання навчального матеріалу за модульними технологіями також дає можливість формування гнучкого графіка організації занять, зокрема, у форматі переривчастих курсів тематичного удосконалення [2, 3]. В ДЗ “ЗМАПО МОЗУ” розроблена та впроваджена нова організаційна форма професійного розвитку лікарів-постійно діючі проблемні семінари для лікарів первинної ланки медико-санітарної допомоги. Відповідно до пріоритетів Національного плану дій 3 реформування галузі охорони здоров'я, організаційна структура таких семінарів передбачає не лише проведення тематичних занять (лекцій, семінарів- конференцій, майстер-класів, круглих столів), а також надання консультативної та організаційно-методичної допомоги закладам практичної охорони здоров'я.

За принципами відповідності змісту навчання реальним умовам роботи практичних лікарів у ДЗ “ЗМАПО МОЗУ” розроблений та апробується новий навчальний формат проведення інтенсивного курсу інформації та стажування з майстер-класом. Навчальний цикл складається 3 дистанційного (підготовчого) та очного (практичного) модулів, що сприяє

\section{Література}

1. Про затвердження Концепції розвитку вищої медичної освіти України : наказ Міністерства охорони здоров'я і Академії медичних наук України від 12.09.2008 p. № 522/51.

2. Про удосконалення післядипломної освіти лікарів : наказ Міністерства охорони здоров'я України від 10.12.2010 p. № 1088 .

3. Про затвердження змін до положення про проведення іспитів на передатестаційних циклах : наказ Міністерства охорони здоров’я України від 07.07.2009 p. № 484.

4. Вороненко Ю. В. Безперервний професійний розвиток лікарів і провізорів - нові принципи побудови системи оптимізації викладання з цільовими витратами аудиторного часу на відпрацювання медичних технологій.

Як складова моніторингу якості освітньої діяльності, в академії впроваджено технології зворотного зв' язку з учасниками навчання. Відгуки респондентів доводять про досягнення задовільної мотивації лікарів щодо здійснення власного безперервного професійного розвитку у співпраці із закладами післядипломної освіти за умови забезпечення високої інформаційної насиченості і практичної спрямованості інтенсивного навчання за сучасними освітніми технологіями.

Висновки: 1. Завданням сучасного етапу освітньої реформи в Україні $є$ приведення системи підготовки медичних фахівців у відповідність до міжнародних стандартів за сучасними організаційними формами і технологіями навчання з використанням позитивних рис європейських освітніх моделей.

2. Застосування нових організаційних форм навчання і сучасних освітніх технологій в межах традиційної післядипломної підготовки сприяє підвищенню мотивації лікарів до активного безперервного професійного розвитку.

3. Впровадження в педагогічну практику принципів сучасного клінічного навчання, доказової медицини, біоетики, медичного права та клініко-економічних стандартів 3 найбільш медико-соціально значимих нозологій відповідно до міжнародного досвіду сприяє збереженню традиції національної системи медичної освіти $з$ підготовки та виховання сучасного спеціаліста.

/ Ю. В. Вороненко, О. П. Мінцер // Нові напрямки впровадження кредитно-модульної системи організації навчального процесу у вищих медичних і фармацевтичних навчальних закладах України III-IV рівнів акредитації : матеріали Всеукраїнської наукової навчально-методичної конференції. - Тернопіль : ТДМУ, 2011.-С. 26-28.

5. Никоненко О. С. Проблемні питання впровадження безперервного професійного розвитку лікарів на етапі реформування системи вищої медичної освіти / О. С. Никоненко, С. Д. Шаповал, С. М. Дмитрієва // Медична освіта. 2007. - №4. - С. 4-6. 